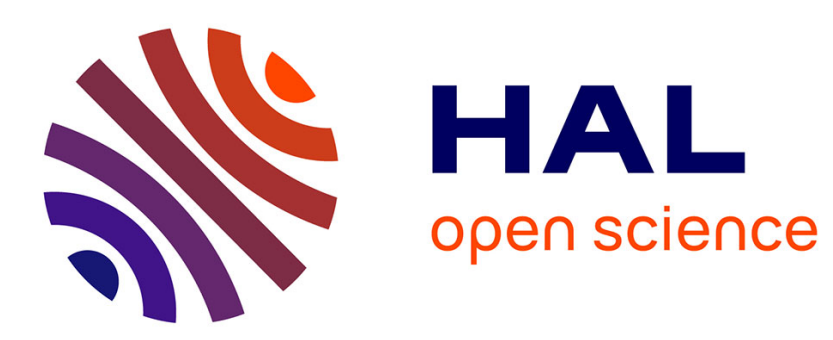

\title{
How can imitation counterbalance innovation? An ABM Bass model for competing products \\ Philippe Collard, Wilfried Segretier
}

\section{To cite this version:}

Philippe Collard, Wilfried Segretier. How can imitation counterbalance innovation? An ABM Bass model for competing products. IEEE RCIS 2014 Eighth International Conference on Research Challenges in Information Science, May 2014, Marrakech, Morocco. hal-01288467

\section{HAL Id: hal-01288467 \\ https://hal.science/hal-01288467}

Submitted on 15 Mar 2016

HAL is a multi-disciplinary open access archive for the deposit and dissemination of scientific research documents, whether they are published or not. The documents may come from teaching and research institutions in France or abroad, or from public or private research centers.
L'archive ouverte pluridisciplinaire HAL, est destinée au dépôt et à la diffusion de documents scientifiques de niveau recherche, publiés ou non, émanant des établissements d'enseignement et de recherche français ou étrangers, des laboratoires publics ou privés. 


\section{How can imitation counterbalance innovation? An ABM Bass model for competing products}

\author{
Philippe Collard \\ Univ. Nice Sophia Antipolis, CNRS, I3S, UMR 7271 \\ 06900 Sophia Antipolis, France \\ Email: philippe.collard@unice.fr
}

\begin{abstract}
which presented a theory of the adoption of new products. We propose an agent based modelling to allow to model the respective grow of competing products. We assume that there is competition for the same market among two trademarks: each one has its own rate of spontaneous innovation and its own rate of imitation. This paper deals with the relative weight of these competing behaviours on the global dynamics; in particular, we ask the question of the equivalence between mass media influence and word-of-mouth effect.
\end{abstract}

Abstract-The general context of this paper is the Bass model

Keywords-Agent based modelling, Bass model, Marketing, Competing products

\section{INTRODUCTION}

The major development of the diffusion of innovation theory is attributed to Everett Rogers; in his works he indicated that the spread of a new technology depends on innovation or imitation [1]. In the seventies, Frank Bass proposed a simple model of diffusion of innovation [3][2][6] where the innovation and imitation factors shape the speed at which the technology is adopted. There are three parameters: $N$ the market potential; $p$ the rate of spontaneous innovation/adoption (i.e. mass media influence); $q$ the rate of imitation (i.e. word-of-mouth effect). $A(t)$ is the fraction of customers who have adopted the product at exactly time $t$ since introduction. equation:

Aggregate Modelling: $A(t)$ follows the differential

$$
\frac{d A(t)}{t}=(p+q \cdot A(t)) \cdot(1-A(t))
$$

and the solution follows a S-shape if $(q>p)$ with $A(t)$ tends to 1 in the limit.

As the Bass model is versatile and allows prediction, it became one of the most popular in the field of marketing. For instance, table I gives parameters $p$ and $q$ from a cross-section representing different categories of products $^{1}$ : on average, we obtain $p=0.03$ and $q=0.38$ [5].

Agent Based Modelling: Following the guidelines for rigorous $\mathrm{ABM}$ modelling in marketing proposed in [4], we build an $A B M$ that produces similar results to the original analytic Bass model (algo. 1) ${ }^{2}$. Thus, in the following, we shall be able to investigate what happens when two products compete for the same market.

\footnotetext{
${ }^{1}$ http://faculty.washington.edu/jdods/pdf/MktgTool $\backslash$ _Bass.pdf

${ }^{2}$ To reproduce the results of the analytic Bass model, the agents are assumed to neighbour all other agents in procedure IMITATE (algo. 1).
}

\author{
Wilfried Segretier \\ LAMIA Laboratory \\ University of the French West Indies and Guiana \\ Email: Wilfried.Segretier@univ-ag.fr
}

TABLE I. PARAMETERS $p$ AND $q$ FROM A CROSS-SECTION OF CATEGORIES

\begin{tabular}{|c|c|c||c|c|c|}
\hline Product & $\mathrm{p}$ & $\mathrm{q}$ & Product & $\mathrm{p}$ & $\mathrm{q}$ \\
\hline \hline Cable TV & .100 & .060 & VCR & .025 & .603 \\
\hline Camcoder & .044 & .304 & Dishwasher & .000 & .179 \\
\hline CD player & .157 & .000 & Microwave & .002 & .357 \\
\hline Cellular & .008 & .421 & Hybrid Corn & .000 & .797 \\
\hline Home PC & .121 & .281 & Radio & .027 & 0.435 \\
\hline Ultrasound & .000 & .534 & Tractor & .000 & .234 \\
\hline
\end{tabular}

\section{COMPETING MODEL BASED ON AN ABM BASS MODEL}

While the Bass model was initially proposed for forecasting the adoption of a new product for which no closely competing alternatives exist, we relax this constraint by assuming there is two competing products for the same market. This means that (i) initially all customers are set to the state of not having adopted none of the two products; (ii) one customers can adopt only one of the two products; (iii) the main algorithm (algo. 2) stops when all the customers have purchased one of the two products. The output of the model is the gain of $P_{1}$ relative to $P_{0}: g=\frac{2 . V-N}{N}$ where $V$ is the number of products $P_{1}$ adopted at the end of the run. If $\left(p_{0}, q_{0}\right)=\left(p_{1}, q_{1}\right)$ there will be as many adopted product $P_{0}$ as product $P_{1}$ and so the gain is null. If all the agents adopt $P_{0}$ (resp. $P_{1}$ ) then $g=-1$ (resp. $g=+1)$.

We use the NetLogo multiagent programmable modelling environment [7]. The space is a 2-dimensional grid connected circularly and simulations are performed on a rectangular lattice composed of $N=20000$ agents. We fix the parameters for the first product to $\left(p_{0}, q_{0}\right)=(0.03,0.38)$ (see tab. I)) and $p_{1}$ and $q_{1}$ will vary from 0 to 1 . The question is on the influence of both innovation and imitation when a product competes with one other for the same market. To study the relation between the input parameters and the resulting gain, we draw the 3-D surface $S$ of all the points $\left(p_{1}, q_{1}, g\left(p_{1}, q_{1}\right)\right)$. To know if there is a functional relation between innovation and imitation in case of equivalent gain, we pay special attention to contour lines in $S$ where $g\left(p_{1}, q_{1}\right)$ is constant.

Gain vs. innovation and imitation (fig. 1): (i) If innovation is high, say $p>0.6$, the gain is close to 1 ; (ii) if innovation is relatively high, say $p>0.4$, imitation has a low influence on the sales volume; (iii) if innovation is low, say $p<0.1$, the role of imitation is significant as the gain increases with $q$.

Study at constant gain: Running simulations on the set of couples (innovation, imitation) such that the gain is constant results in equation $q=\alpha \cdot \ln (p)+\beta$ (fig. 2). 

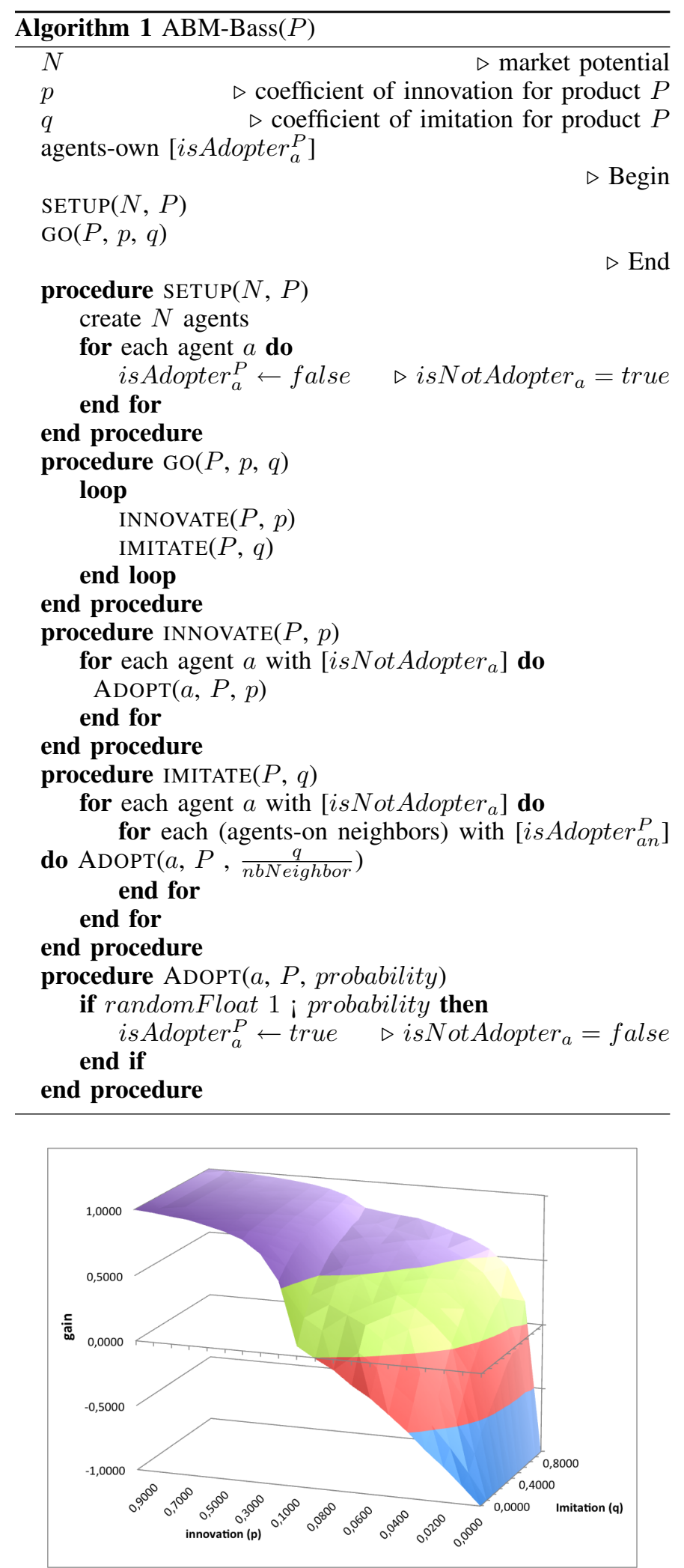

Fig. 1. Gain of $P_{1}$ relative to $P_{0}$

\section{CONCLUSION}

The question of the counterbalance between innovation and imitation is important, because answers to this question guide a
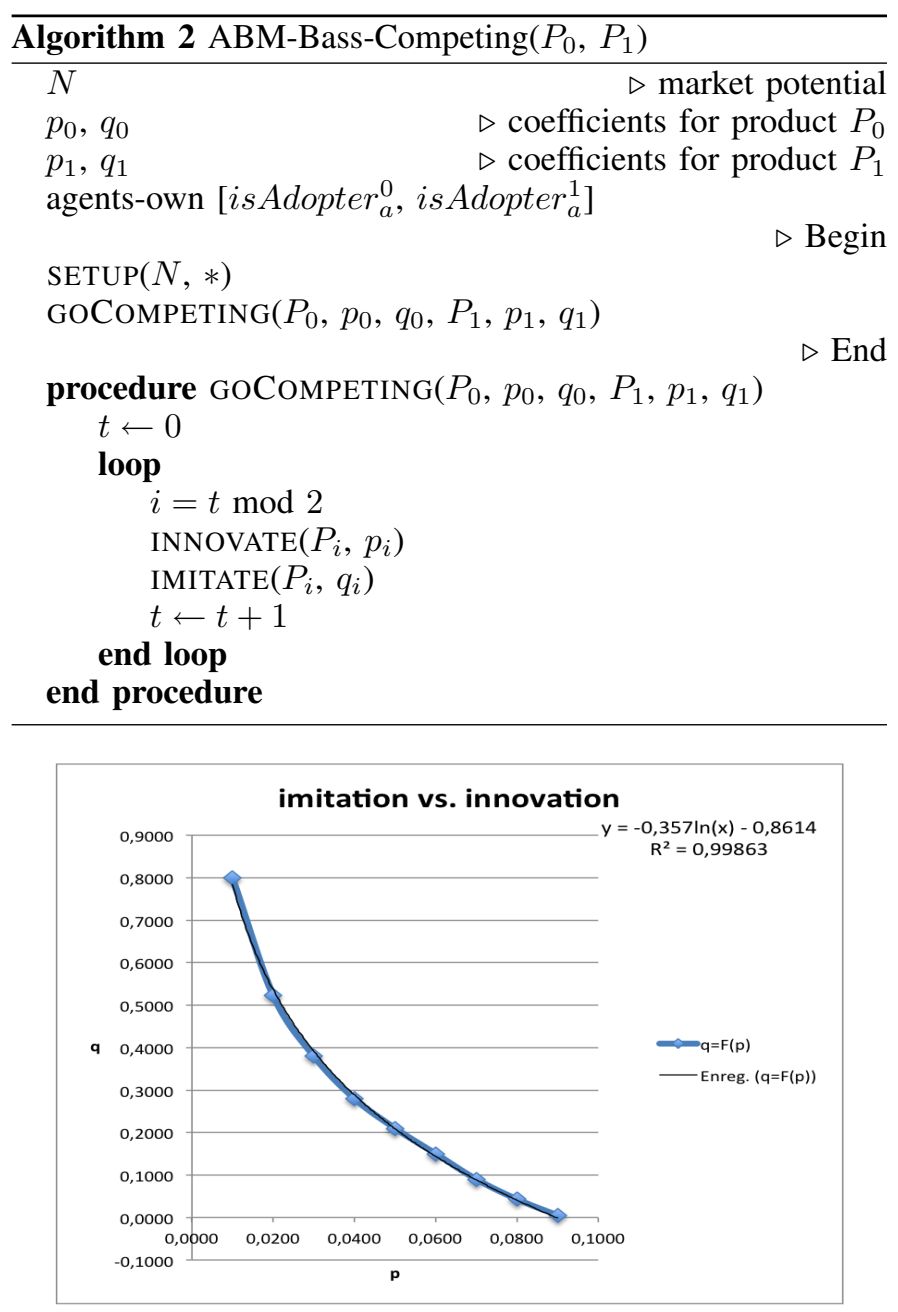

Fig. 2. Imitation as as function of innovation for $g(p, q)=0$

firm in its deployment of resources in marketing the innovation or in favouring imitation via social networks. The main result is that on can counterbalance a quadratic change in innovation by a linear change in imitation.

\section{REFERENCES}

[1] Rogers, E.M., Diffusion of Innovations, 4th ed. Free press, New York, 1995.

[2] Bass, Frank M., Comments on "A new product growth for model consumer durables.” Management Science, 50, 12, pp 1833-1840, 2004.

[3] Bass, Frank M., A new product growth model for consumer durables Management Science, 15, pp 215-227, 1969.

[4] William Rand and Roland T. Rust, Agent-based modeling in marketing: Guidelines for rigor International Journal of Research in Marketing, 2011.

[5] Lilien and Rangaswamy, Marketing Engineering, Revised Second Edition The Free press, New York, 2004.

[6] Dodson and Muller, Models of New Product Advertising and Word-ofMouth Management Science, 1978.

[7] U. Wilensky, Center for Connected Learning and Computer-Based Modeling http://ccl.northwestern.edu/netlogo/, Northwestern University, Evanston, IL 1999. 